\title{
On Company Field Training
}

\author{
Major A. W. A. Pollock
}

To cite this article: Major A. W. A. Pollock (1897) On Company Field Training, Royal United Services Institution. Journal, 41:229, 296-314, DOI: $10.1080 / 03071849709416008$

To link to this article: http://dx.doi.org/10.1080/03071849709416008

\section{曲 Published online: 11 Sep 2009.}

Submit your article to this journal 준

LII Article views: 2

Q View related articles $\longleftarrow$ 


\section{ON COMPANY FIELD TRAINING. \\ By Major A. IV. A. POLLOCK, The Prince Albert's (Somersetshire Light Infantry".}

Wednesday, December 9th, 1896.

General Sir Richard Hakrisox, K.C.B., C.M.G., R.E., in the Chair.

The Cratryax :-Ladies and gentlemen, $I$ have much pleasure in introducing to you this afternoon Major Pollock, of the Somersetshire Light Infantry. I think I may mention, before he begins his lecture, that he is not only a theoretical soldier but a practical one, that is to say, every word that he has written he has practically tested in the field. I can testify to his company having been one of the best trained that it has ever been my pleasure to sec. Without saying anything more, I will ask Major Pollock to read his lecture.

\section{I.ECTURE.}

THE application of drill to tactics stands upon a very different footing in the infantry to that which it occupies in the cavalry. Formerly there was no such distinction. In the days of smooth-bore muskets battalions were trained exclusively as battalions to fight as battalions, and their efficiency in battle depended upon the precision with which they could conform, not only to the will, but also to the voice of their commanders. In the present day the conditions of infantry fighting are entirely altered, and the several companies of which battalions are composed may be said to have discarded unison in favour of harmony: That is to say, in other words, whilst it is imperative as ever to aim collectively at a single tactical objective, the companies can no longer be controlled and guided by the one voice of the lieut.-colonel, but must. severally endeavour to carry" out his intentions so far as the special conditions attending the operations of each will admit. In short, an infantry commander is no longer in a position to do much more than indicate, generally, the task to be performed, and must be content to leave the details to the discretion of the subordinate leaders upon the spot, without direct supervision upon his part. 
Thus the ultimate responsibility falls upon captains of companics, because even in the case of weak battalions the lieut.-colonels are unable to exercise any general command after the moment when the companies become actively engaged in the fight. The training of infantry, therefore, demands that the companies shall be so instructed, individual'y, that they may be thoroughly capable of severally performing their allotted parts in co-operation with each other. supporting one another, and expecting to be similarly supported. All have the same general object in view, but, although the whole combine harmoniously for a single end, they do so, each by the particular methods dictated by the circumstances attending its own action. Such independence in the choice of means, qualified by unity of purpose, can best be cultivated by instructing the companies, singly, at field training. Perfect discipline displayed by instant and implicit obedience to all orders, including thorough control of fire, is the very essence of successful infantry tactics. Drill in the infantry is the mainspring of discipline, but parade movements have no place upon the battle-field. In the cavalry, upon the contrary, drill is not only the foundation of discipline, but also the soul of mancurre and the backbone of the charge. Cavalry manouvres up to the very moment of charging, and squadrons, however well trained individually, would be at the mercy of adversaries more familiar with the drill of masses. But, in the infantry, a really well-trained company is already a useful fighting machine. The manæuvres of large bodics are for infantry only objectlessons illustrating, practically, the theory of combination already explained to the companies, and represent the final polish needed to perfect an already well-made and highly-finished article. If the article in question, namely the company, is not already well and truly fashioned, the polish of mancurres is wasted upon it, and the futile attempt to give it may even do more harm than good.

A number of companies, all of them well trained individually, fall readily into their places for combined action, although they may have had but little recent practice in battalion or brigade. The idea of combination will have been instilled during company training in conjunction with at least one other company, and a rough and ready application of the theories thus acquired will fairly answer the purpose.

The case of cavalry is totally different, because thorough familiarity with the drill of large bodies is essential to tactical efficiency. Perfect order, as if on parade, is required, not only whilst manœurring for advantages in the initial situation, but also during the actual charge itself. This cannot be acquired by squadrons individually, and all that squadron commanders can effect in this direction is to make their squadrons fit material for the hand of the superior officer who welds the entire machine together. From a fighting point of view squadrons are trained, individually, only to render them capable of being trained to fight collectively, but the infantry companies at field training are prepared directly for their places in the fight. Battalions detailed for the firing line must quickly be dissolved into their elements, that is to say, become merely so many companies, from the moment that they enter the fight; 
but cavalry, unless the squadrons drill together like clockwork right up to the actual shock, is useless unless opposed to still worse trained adversaries. It is only when a squadron is detached or is detailed for some distinct duty that it is enabled to display its particular merits as an individual squadron; but an infantry company, whether on outpost duty or in the fighting line of a general action, is usually dependent far more upon the common-sense application of general knowledge than upon any drill, except musketry drill, that it has learned upon the barrack square.

In the forefront of an infantry fight, drill manourres are impossible; but the discipline, especially fire discipline, so essential to success, is wholly dependent upon the drill by which alone it can be acquired. When troops show good fire discipline, they demonstrate the fact that their general discipline is so good that force of habit obliges them to use their weapons in the manner learned at drill as often as they are ordered to do so. With this much secured, the rest can be taken for granted. A state of discipline which is capable of causing men whose nerves are highly strung by danger and excitement, to fire steadily by word of command, with good aim, and sights correctly adjusted, at the targets indicated from time to time, will also suffice to urge them onwards as often as they are called upon to advance. Fighting discipline is after all nothing but the habit of obedience, aided by esprit de corps and the courage of individuals. When the recruit is taught to handle his arms, and to perform all drill movements smartly-moving like lightning at the last sound of the word of command-he is already learning the habit of obedience, to be afterwards demonstrated by fire discipline.

Bearing this in mind, it appears desirable to point out, before procecding to discuss the subjects to be taught at company field training, that captains of companies incur a grave responsibility if they fail to exact the utmost smartness from their men at all times during the training. Smartness is after all nothing but cleanliness, soldierly bearing, steadiness in the ranks, and prompt obedience to every word of command. Smartness as regards drill itself can only be gained by constant practice, and in the process the habit of obedience is acquired. Without reasonable smartness at drill, no proper fire discipline can be established. The original parade polish will lose its lustre on active service, but so long as the slightly clumsier attempt to comply with an order follows instantly upon the order, the lack of finish need not be hurtful. In any case, only a battalion of veterans can afford to be slovenly in its drill. Some officers appear to imagine, because their companies are at field training, or at musketry, that the barrack square may be relegated to oblivion. This is a great mistake. When men are standing easy or marching at ease, by all means give them freedom to do as they please, so long as they do not make too much noise or get out of their places without permission; but at other times the precision and smartness of drill should invariably be exacted. The fact that polish will be lost upon active service is no reason why its brilliancy should be permitted to diminish prematurely. Polish is easily lost but not so easily regained, and there is more in it than some people appear to admit. The secret of securing steadiness in 
the ranks is to aroid overtaxing men's endurance by keeping them too long at attention; and last, but not least, never to allow "Stand at ease" to be thought equivalent to "Stand easy." Finally the officers must themselves set an example of personal smartness fit for the men to imitate; and must further remember that smart drill without a smart word of command is impossible. Companies do not go to ficld training to learn their drill, but to learn how to apply it in the fight, by the preservation of order and the maintenance of fire discipline. Drill is not directly applied in battle, but holds its sway as the school in which discipline is acquired.

An apology is due for so long a preface, but the object of what has been said is to indicate the standpoint from which the real subject is intended to be approached. The syllabus given in Part X., Infantry Drill, may be taken as a general guide to captains of companies, provided, not as an unalterable programme to be followed implicitly, to the destruction of their own initiative, but simply in order to detail the various branches of instruction which they are required to undertakc, according to whatever method pleases them best. Judgment will subsequently be given according to results, quite irrespective of the particular methods employed.

The preliminary weck with the N.C. officers is too often treated somewhat in the nature of a farce. Officers know so well that a man who has never executed a sketch in his life cannot be fully instructed in six days, and, therefore, they often fail to teach even the little that can be acquired in so short a time, forgetting that if the rudiments are thoroughly grounded this year, better things can be done in the jears to follow. But eren in the first year a great deal more can be accomplished than might at first be supposed, provided that the face is sternly set against attempting too much, in the effort to avoid doing too little.

But little time should be wasted over conventional signs. Beautifully embellished copies of conventional signs are an abomination. The roughest pencil copies of signs drawn for the class upon the blackboard are amply sufficient so long as they are reasonably intelligible.

The theory and rough construction of simple scales can be taught to most men of ordinary intelligence; and in any case a man is not worth teaching who cannot be made to understand that given a piece of cardboard, divided into equal distances, of suitable length, or a penny ruler, he has only to call those equal distances hundreds of yards; and if he cannot himself discover the scale upon which he thus constructs a map, someone else can readily do so aftèr it has been made. NIen can also be quickly brought to realise the difference between the true and the magnetic North, and that ordnance maps are made with reference to the former. A little practice in setting maps upon the table. will instil this into their minds. This much donc, the methods of finding onc's position can generally be made clear. The meaning of contours can be explained without necessarily going at all deeply into horizontal equivalents or the system of proceeding to contour a sketch. But a light touch of these matters will enable the class to ascertain the gradients presented by given 
slopes. When the members of the class can follow a road upon the map and state correctly where it rises sharply, falls gently, or follows a flat, the situation may so far be regarded as satisfactory, and the next thing is to gain a knowledge of how to find the way from place to place by map and compass, and to show that the scale of the map is understood by giving the distances upon it between the points named. Some of the class may be found worth teaching the system of plane table sketching, and possibly one or two may be amused with the prismatic compass; but the thing to be chiefly aimed at is to teach the whole how to make an "eye sketch" with the aid of nothing but a penny ruler and a pencil. Working with the pocket compass is unsatisfactory, and this instrument should be used merely in order to mark the North point upon the sketch after the paper has been set in the direction of the 2nd Station.

The penny ruler is an admirable instrument for the purpoic in view. Taking a quarter of an inch as representing 100 yards, we have a scale of rt+o0, or 4.4 inches to the mile - quite as small a scale as the majority of N.C. officers can use with any reasonable accuracy. For first instruction, the half-inch to the 100 yards should be used in executing a short sketch, in or near barracks, just as a start in out-door work.

Then, to give an interest in the final out-door exercise something of the following nature can be attempted. Find a place where two roads branch off at an angle, say north-east and north-rrest, and choose four points upon a line passing east and west, upon a front of, say, two or three miles cutting the two roads. There should be field paths and lanes within the area thus enclosed. Assume that the company, in four sections, has been ordered to reconnoitre northwards, from the fork of the roats, and finally to reach posts of observation at the four points already named. The N.C. officers, in four groups, represent the sections. Indicate an intermediate line upon which all four parties are to communicate before advancing further, and direct that communication is also to be established at other times as often as practicable. Fach group is to sketch the route by which it reaches its objective point, and also the off-sets by which it effects communication with the adjacent groups. Such an operation has been successfully performed by the N.C. officers of a company, and in it the N.C. officer in charge of No. 4 Group was obliged to effect his communication with, No. 3 by means of a compass bearing that he himself had previously taken from the map, by which he crossed a considerable park, heavily timbered, including a thick cover, inside the gates of which park he had never previously entered.

During the indoor work for preliminary instruction, at least half-anhour every day should be spent in knotting and lashing and in the construction of miniature bridges. By this means, when the company proceeds to its training all the officers and N.C. officers can be rendered proficient instructors capable of properly teaching the men what they have to do. The poles used for aiming-drill tripods form excellent material for miniature bridges, and a couple of shillings worth of cheap cord will supply the necessary lashings. 
When the company performs its training the principal aim must be to ensure that the whole of the programme of work is got through by one means or another. It is of no consequence how or in what order, provided that the work is done well. Instruction in one subject can often be so combined with that in another, that, if favoured by fine weather, a great deal more can be done than if it is attempted to deal with each scparately. Lectures should be carefully prepared and written out before the training is commenced. Extemporary lectures can never get over the same amount of ground, thoroughly, in a given time. Icctures should be frequent and short. It must never be determined to get through a fixed quantity of matter in a particular lecture. Explanations and çatechising take more or less time; and how much, can seldom be estimated. The correct plan is, therefore, to have the lectures divided into subjects, and take one, two, or more of these subjects, according to the passage of time.

Instruction in all the subjects included in the "Programme of work," with the exception of the "Company in action," must be so nearly confined to simply following the instructions contained in the Red-Books, that they may all be dismissed from the present discussion upon the above grounds. The "Company in action" will furnish the text for what follows, but before proceeding to speak of this there are just two points which may be alluded to in relation to "Hasty entrenchments." It should never avoidably be omitted to construct a shelter trench at night, when it is really dark, with the object not only of overcoming the ordinary dificulties in digging the trench under such circumstances, but also to Icarn how to do so without noise. Secondly, it is also a good plan to dig a shelter trench by day, against time. By putting both front and rear rank men of files to work by turns at single tasks, the half-hourshelter-trench may be dugl and finished with no faults, except that some of the tasks will be a trifle too deep, in $14 \frac{1}{2}$ minutes from the order to commence to the order to cease working. This is a useful exercise, and shows men what can be done if needful.

The "Company in action" involves a wide subject, and the captain is, in this, far more dependent upon his general knowledge and his wits than upon anything that he can find in print to read to his men or to furnish rules for his guidance. He requires to have opinions of his own, formed after reading those of others in whose judgment he has confidence. He must base his instruction upon known precedents and established principles, and endeavour to apply the results of his own study in a fashion which shall be readily comprehensible by those whom he is to teach. The general fabric is supplied to him, but he must supply the details-furnish the house, so to speak-himsclf.

The first principle to be impressed upon the men is the importance of preserving order as long as possible in the fight, and the absolute necessity of instantly grappling with disorder when it comes, is come it certainly will. It must be explained that all ranks have their share in the task, and that the force which enables them to fight with credit in spite

"Soil rather difficult and requiring use of "pick." 
of disorder and to regain their lost formations, is the influence of discipline. Badly-disciplined troops, however brave individually, when once thrown into confusion are lost. But well-trained soldiers instinctively hold together, assume temporary formations, and regain their proper order upon the first opportunity. But to enable this to be done, the preliminary training for war must include practice in dealing with the confusion of battle, which will for that purpose be imitated as nearly as can be arranged. With this object it is essential that men shall be made to realise how every great matter is dependent upon lesser ones. All units, large and small, endeavour, to their utmost, to preserve order; but should order be unavoidably lost, the first thing is to reform the lesser units, and from this beginning rebuild the larger ones. Deployment for battle breaks up a brigade into battalions, and the battalions in their turn are dissolved into companies. To some extent also the companies become sections. But, whilst this last is adnitted, it must be understood that the company is divided into sections chiefly for the purpose of local control, and because it is easier to keep a section together than an entire company. It is the business of the men composing a section to keep together in their section, and it is the business of the whole section itself to stick tight to the other sections and preserve the cohesion of the company. Similarly the company endeavours, against greater difficulties, to preserve the unity of the battalion; even a section, however, may become unavoidably extended over too wide a front, or may from a variety $y^{-}$of other causes be so situated that a portion may be separated from the rest of the section. To meet this danger, with a view to securing the speedy re-organisation of the section and avoiding entire loss of order, provision is made for the sub-division of the sections into sub-sections; and behind this again there is the final and lowest organisation which places the men themselves in groups of fours. Men should be made to understand that there can be no excuse for the break-up of a group except by casualties caused by the enemy's fire, or by bad accidents which put men out of action. So long as the men of a group are able to move they must invariably move together, and the single aim of the four men must be to keep with the other groups forming their section. When the company falls into disorder, whether owing to a rush over rough ground, a charge, losses, or a reverse, every: man must aim at the re-organisation of groups, every group aim at collecting in the section to which it belongs, and the sections similarly re-uniting in the company. A mob of men trying at once to reform in large units, such as a battalion, can only make confusion more confounded, unless the company markers are placed for them to fall in upon. But if the men have preserved their groups, they have done something towards reforming their sections, and when these are formed they can one by onc reform company, and finally even the battalion can be got in hand. The successful storming of a village or wood is certain to produce confusion, and the maintenance of the position won, against counter-attack, must generally depend upon a prompt restoration of order.

It now remains to indicate the lines upon which work should be 
done, with a view to accustoming the soldier to meet the difficulties and dangers which confusion will bring to him in all kinds of fighting.

Companies are usually struck of duty for field training in pairs, unless circumstances permit a still larger number to be exercised together.

The first thing to do is to train each company, separately, to cope

with the disorder which can be raised in a single company within itself; and, secondly, to proceed with the more difficult task of disentangling two or more which have been mixed up whilst working together.

It will be admitted that before undertaking to restore order it is necessary to have so drilled the men that there shall be an "order" to restore.

The first stage in fighting drill is, therefore, to obtain precision in purely drill manœurres. Dressing of the extended line, preservation of section intervals, intelligent use of cover, direct advance, etc., such as used to be the beginning anct ending of the old attack drill, must consequently be practised, with especial care in reference to the drill features of fire discipline. Having succeeded in getting the company to drill well without difficulties, the next thing is to get fairly good drill in spite of difficulties, and to gradually increase those difficulties until all that can be thought of and imitated have been introduced. In short, first get drill so good that nothing but bullets or very broken ground could produce confusion, and then teach how to work in spite of the greatest confusion that can be artifically created in resemblance of the real confusion of battle.

The system of stages recommended is as follows:-

The regular drill having been pronounced satisfactory, proceed with the further education.

Extend the directing half company; reinforce with a third section to the outer fiank, and subsequently throw the remaining section broadcast into the line. Cause section commanders to tell off temporary sections. When the company is under suitable cover (real or imaginary, but real if possible) re-organise the proper sections:-Thus, section commanders place themselves $1,2,3,4$, and call their men to them on the order " Re-organise." The movement being covered, if ordered, by the independent fire of such men as may already be in their proper sections. Having re-organised, proceed with the attack. Having unfixed bayonets, after the charge, order the men to look to their front, and without their knowing in what order or where they are placed, arrange the section commanders in order, say, $2,1,4,3$, in column facing as you please. Give the order "On section commanders by the right (or left) assemble" (or bugle sound). Nen to double in, find and form upon their own section commanders. No pushing, no talking. All to be in their places ready to form fours the moment the last man has halted.

Such is the first stage.

The second stage consists in a first lesson in dealing with casualties and the confusion arising first by the loss of leaders, and secondly by the introduction of strangers into the line. This latter being simulated by means of the casualties being thrown again into the line. The company is 
extended so that all four sections are brought into the line in their proper order. During the advance, make casualties of section commanders. The first man who notices the casualty is to take command. If a senior wishes then to dispossess this self-appointed leader, he may do so. Repeat the operation until the greater number of the privates, as well as all the corporals and lance-corporals, have had turns in command of sections. A subaltern follows the advance collecting the casualties, and as soon as they amount to about the strength of a section, extends them and sends them broadcast into the firing line. No casualty is again to take command of a section during a single attack. Thus the colour-sergeant having been made a casualty, rejoins the firing line as the junior private, so to speak. Section commanders should be made casualties at awkward moments-during a rush, for instance, or when actually giving orders.

When the company is proficient in dealing with the passage of command from one to another, as one leader after another becomes a casualty, we proceed to the third stage; extend the company as in the first stage, and apply to this the casualty procedure cletailed for the second. But in this stage, in place of touching individuals and making them casualties, order men of all ranks to fall out, as they please, during an advance, during a rush,.or when halted for firing. This gives greater reality, for, however stealthily the captain may endeavour. to make casualties by directly indicating individuals, it is hard to escape observation when doing so, and the great point is that the casualties should occur so as to be generally unobserved until their effect becomes apparent through the cessation of orders or some similar cause.

Finally, when the single company is so trained that any private can on the spur of the moment take command of a section and command it intelligently, in accordance with the orders given for the attack in progress; when temporary units can at any moment be organised by the section commanders for the time being, and when the company can instantly re-organise its proper sections under the soldiers at the moment commanding the sections, without loss of fire discipline and in spite of loss of proper order, then the time has come to work two or more companies together, mix them thoroughly and teach the men to extricate themselves from the confusion, by sections, reform company when opportunity offers, and meanwhile to preserve fire discipline whilst still mixed and working in temporary sections.

When the companies are working together in the final stages, and after the required lessons have been fairly learned, the N.C. officers who have been directed to fall out in order that privates may from the first command sections, can be utilised to represent a skeleton enemy. It is most important to have real men to represent the enemy whenever this is practicable; otherwise the scouting to reconnoitre the enemy's position becomes little more than a farce, and the effect of errors committed during the fight itself cannot receive practical demonstration. Therefore as often as the companies at field training are working together, each should supply a few men to represent the enemy. If the companies were 
to be invariably opposed to one another, practical instruction in combined action could not be given.

To prove that a company has learned its lesson, it should be caused to deliver an attack, the sections being from the first commanded by privates and the whole of the N.C. officers having been previously ordered to fall out. The inspecting officer should choose men from the ranks to command the sections, to commence with, without consulting the captain or any person who knows which are the most competent. The captain should be permitted only to indicate the point of attack, detail the sections, name any special dangers and advantages attending the advance on such ground as can be seen, and then be ordered to fall out and leave the rest to the men. If all that has been suggested is well done during the advance, fair evidence will have been given that loss of leaders and loss of order need not destroy fire discipline or the orderly prosecution of the attack, in spite of the utmost apparent confusion of all original organisation.

It only remains then that the whole battalion shall be exercised upon similar lines. Different systems for extricating the companies from the . mob will occur to different officers; but so long as the methods employed are simple, and found to answer the purpose, the desired result has been attained. Celerity and simplicity are the objects to be aimed at.

History proves that success as well as failure produces disorder. 'The lisorder is inevitable, and cannot be prevented by any system whatever. The object of our training should, therefore, be to enable good work to be done in spite of whatever disorder or confusion is encountered. So long as troops work in units by word of command, and show therein good fire discipline, they can win victories, whether the units are temporary ones, improvised from time to time, or the original units formed upon parade.

The company executing an attack without officers or N.C. officers is not a fancy picture-I have seen this done myself-nor do I recommend anything clse which has not already been successfully attempted by soldiers now serving.

My opinion on rushes rests upon a very simple basis, and I think a practical one. Most of you will have read of the right attack on Lc Bourget, by the Alexander Regiment of the Rifles of the Guard. The firing line of the regiment was divided into two echelons, that is to say, the rushes were executed by alternate halves. These rushes commenced, in consequence of the ground being open, at a distarice of some $\mathbf{2 , 0 0 0}$ yards from the enemy's position. 'There was no cover available, except cover from view, afforded by certain fields of standing potatoes amongst which the men threw themselves at each halt. The attack was successful, without very serious loss, and this in spite. of the fact that it was not strongly supported by artillery. Prince Kraft bases upon the success of that attack a theory which I venture to recommend to you. I do not remember the exact words, but it is to the effect that no attack directerl against a single objective should be divided, for the purpose of rushes, into more than two echelons; the advantage of this being that when the one rechelon rushes to the front, that which remains in rear can maintain its 
fire throughout the advance, and after the completion of the advance of the echelon which has rushed to the front. By this means you gain two advantages, as compared with the old system that we had of alternate sections or half-companies as the case might be. Where small units all along the line rush to the front, they mask the fire of all those left behind. Therefore the fire of the entire firing line is absolutely paralysed from the moment that the rush is commenced. By the means which $I$ have described, you can not only aroid that paralysing of the fire, but can also afford to make the rushes longer. By using long rushes you reduce the number of exposures, and also give greater difficulties to the enemy in getting the range. Moreover, as the echelon in the rear can continue firing during and after the advance of that one which has gone on, you can not only make the rush longer, but you can also give pause at the end, for the men to recover breath, before they resume firing. We rush 40 or 50 yards, and a section is considered smart if it opens fire on the spot, the moment it gets there. I should like the rush to be 100 yards, when possible, and a distinct pause to be made for the men to recover their breath, and think about what they are going to shoot at. Then we come to what will have occurred to many people, viz., that if you are rushing by ${ }^{\prime}$ half-battalions, it is practically impossible for the whole of a halfbattalion to jump up as one man and rush together. Before we get to rushing, I think we must start with the idea-assuming the centre of the line to be directing-that the directing half should not only direct, but lead, the advance, i.e., be the first to rush when the time for rushing comes. And, secondly, I think that you should begin to rush before you are obliged to do so. If men want to go on, and the general line cannot proceed; it is obvious that rushes will come spontaneously, that is to say, units which think they sec some opportunity of gaining ground, will rush to the front and give an example to others who will align themselves with them. But it is my opinion that you should begin rushing before you are obliged, so as to establish a system of hand over hand, one half shooting and one half advancing, before the enemy's fire becomes really destructive and renders such an organisation difficult, if not impossible to inaugurate. A half-battalion-much less two battalions of a brigade, by half-battalions-could not expect to advance like one man the moment someone whistles; but if you commence by sections, like a peal of bells, from the directing section, the operation becomes easy. Supposing there is somebody in command of the firing line, or if there is not, let the officer commanding the company, in which the section of direction is, blow his whistle and give the "Advance" signal. Supernumeraries pass the word along the line: "Right (or left) half, prepare to rush"; which means that every section fires the volley it may be about to fire, without hurry, and then ceases fire. Having given a short pause for this to be done, the whistle and signal are repeated. The commander of the directing section jumps up, "No. 4," or No. 1, or whatever it may" be, "Rush." The others follow in succession at about three or four paces distance. The line thus gets up by sections from the inner flank to the outer. Neanwhile, the other echelon, left in rear, is shooting all the time. 
Major-General M. W. E. GossET, C.B. :-The inportance of this subject cannot be over-rated. I an sure that those who have listened to the lecture will agree generally as to the soundness of Major Pollock's system of company field training. I am glad to sec that he lays great stress on the necessity of steady drill and parade ground discipline. I am inclined to think that there may be a tendency to let this slide; whereas the fact is, that with the improved firearms of the present day it is more than ever necessary. Strict discipline is the key-note of the whole business. I bave had a good deal of experience in India in field training, and its general introduction into our Service has been of great benefit. It is not altogether something new, its necessity having been felt in old days; and it was carried out in my regiment and others after a fashion, though not with the thoroughness it is now: We have officers of various capacity and the training, consequently varies. If all paid as much attention to it as Major Pollock, and had as much knowledge as he has, it would be a good thing for the Service. The test of a company's training is the way in which it works during brigade or other manouvres. If the training has not been thoroughly well done, a general officer finds himself handicapped. In the mancuvres in India that I have taken part in, I have had to remark that battalion and companies have come inadequately trained. I am not quite sure whether I am right in saying so, but I believe the training of recruits in Sec. 4i; Part I., of the Drill Book, "Drill of a section in extended order," is not always so goud as it might be. A recruit should be handed over to his captain well grounded in the A B C of this part of his drill. A drill sergeant generally teaches him smartness, steadiness, and how to handle his arms; but it requires a soul rather above the ordinary drill to teach the principles of extended order well. Major Pollock, in his lecture, tells us how he would utilise casualties. I am not aware that the system of falling out men as casualties is authoritatively laid down anywhere. It may be a necessity in order to teach them our sy'stem of attack, but in peace-time we want to teach men what to do in war, and I have long thought that to make men fall out when at manocurres is a mistake. We all know what human nature is. If all men were equally brave and would advance regardless of the bullets flying about their heads, it would simplify matters considerably; but they are not, and the revelations of Von Hoenig show how difficult it is to get men to face a heavy fire. Is it not, therefore, a mistake to allow casualties? This leads to another point, with reference to the attack by a battalion or brigade. 1 fully recognise how necessary it is, to teach men to work in sections or groups and to re-organise rapidly. Whatever our system of attack may be, disorder is inevitable sooner or later; but at the risk of being thought heretical, I think we rather go out of our way to create disorder at a considerable distance from the enemy. For example, suppose in the attack by a brigade, a battalion is given a certain frontage in the firing line. sccording to the systems generally adopted, a certain number of companies are told off to make the firing line, and each of these companies in the first instance extends one section to occupy this frontage. These sections are reinforced, and thus carly in the altack there is a mixing of units. His Royal Highness the Duke of Connaught, in his report on the late nuanceurres at Aldershot, says, "I endeavoured to point out that it was necessary, in order to keep down the enemy's fire, to make the line as dense as possible from the beginning." Now, if this is the case, my contention is, that it would be far better, instead of mixing the units, to keep them intact; and the only way to do this is to send whole companies into the firing line-in fact, base your system on the old British line. The evil of ordered disorder would be minimised if all men were trained as the lecturer trains his men; but on the outbreak of war, supposing we put two army corps in the field, they would be composed of a certain number of old soldiers, many young ones, Reservemen, and; perhaps, volunteers from the Militia. Wars nowadays begin rapidly, are carried on rapidly, end rapidly, and it is doubtful whether there would be time to train them up to the standard neces- 
sary. Good discipline and the fighting instincts of the race will cover a multitude of sins; but, I think, the longer you can keep unitș together under their own officers and N.C.O.'s the better.

General Sir William Gordox Cayerox, K.C.B. :-I only wish to add mytestimony to the very important nature of the subject that we have before us to-day: I have had a good deal of experience as a general officer in superintending this company training since first starting it in my brigade at Aldershot in 1879 ; and all I can say is, that I most cordially agree that there can be no big satisfactory manceuvres without this preparatory work. I do not believe that the country will get a proper return for its money, with regard to the expenses in preparing for big manceurres, unless the companies have been previously thoroughly well trained. I quite agree with what the lecturer has said with regard to all those principles he has enunciated in the preparatory" part of his lecture; and I go farther and say, that if the companytraining is to be of that very superior character which we require in a very small and scattered Army like ours, that the captain has to sit down at night and prepare for the following day's work in the most thorough manner, just as we prepare at this Institution for our war games, and so on. He cannot cogitate too deeply, to the best of his ability, over the proposed course (theoretical and practical) for the training of his men, or carry it out thoroughly. I have found theoretical trainingwe call it theory, but after all practice consists in going out on the ground to simply illustrate what we have been teaching the men in the barrack-room-of the greatest use in raising the standard of intelligence on the part of the men. I have found it of the utmost importance to attend myself in the barrack-rooms, and by means of catechising the men to thoroughly implant what it was wanted to teach them. Mere lecturing without catechising, in language the men can understand, is like too long a sermon, of which you do not carry very much away; but by at proper system of catechising the men in the barrack-rooms you can raise the standard of their intelligence to a very considerable extent, and you can thoroughlyteach them those rules that you afterwards have to apply in the field. I would also remark that you require a different set of umpire rules for small mancurres. This is a very different thing from the umpire rules for large masses of troops where the men absolutely hear nothing of what has been done, and go home, as I used to say in my reports, about as wise as when they came out. They do not read, most of them, the comments made afterwards, and they really very often learn uncommonly little. But if in these mimic manœurres, company against company and so on, you have the men up and confront one party with the other, and thoroughly thrash out and explain to them on the spot all that has taken place, then you get good results. You call out even non-commissioned officers and private soldiers, and say, "Come forward and tell us why you did that to-day"; and they have to stand forth before their comrades and endeavour to explain. You thus excite an immense amount of interest and feeling of responsibility on the part of the men. Tommy Atkins begins to think then, and he is proud of himself when justly commended. If some patrol or outpost or sentry has done well or badly, and is shown up on the spot before the troops are dismissed, you may relyupon it that much more is gained from the impression made than by the usual after-criticism in print, and when the facts are either not realised or have been forgotten. As regards the exercises comprising the annual course of company training, it should be recollected that this is the only time the captain has his men together under his own command, and that they are struck off all garrison and regimental duties for the purpose of forning, once in a way, a complete tactical unit. This being so, you want to teach them what they cannot otherwise very well learn; and this I take to be their tactical work in connection with attack and defence of positions, rear-guards, advance-guards, outposts, ambushes, etc., etc. I am sure there is nobndy here who will not agree with me that the most difficult thing to learn is quick appreciation of ground and how to utilise it for attack, 
defence, pursuit, retreat, and so on. When you call the men together for this purpose, I think it is a mistake teaching them a lot of technical work, such as camp work, field engineering, etc., etc., which form part of the prescribed course. I say. that you can teach all this during the rest of the year, without the whole company being necessarily together. Besides, men pick up all these things very quickly, and I maintain that nearly the whole time the company is struck off duty ought to be devoled to tactical work, and I think it is a waste of time if you employ the company in any other way. I understood the lecturer to say that if you want a thing thoroughly done, you should strike one company off duty at a time, instead of in pairs.

Major Pollock :-No, sir. By all means in pairs.

Sir Willias Camerox :-Of course, in a great camp such as Aldershot you have to strike off in pairs. I found in South Africa the best plan, if there was time, was to strike single companies off duty, and then insist upon six tactical exercises, conducted in accordance with Part X., Infantry Drill. The enemy being furnished from the rest of the battalion, you then not only kept the companies thoroughly well going as long as the period of company training lasted, but you also kept the other companies fairly at work, so that there was perpetual training going on. I do wish to impress upon all $\mathrm{my}$ brother-officers the enormous importance of this company training. I am only saying here what is recognised over the whole Continent, where the greater part of the time is taken up with thoroughly training all the units. If I were to take the field to-morrow with a lot of troops, give me thoroughly well-trained battalions, though they may not have been working together in brigades, divisions, or larger bodies. Of course, it is a very good thing when you can have large masses of men brought together; but if the units are perfect, if they are perfectly trained, then the general, after a few days or a few weeks, as the case may be, ought to have a splendid command, and be able to take the field against any enemy. But it is absolutely necessary, before you proceed to bigger operations, to have your units perfect.

Colonel W. T. DOONER (commanding 87th Regimental District):-I am sure that all who have listened to the lecturer will agree that he has given some very valuable suggestions and hints to officers commanding companies when at field training. If there are any company commanders here to-day they may perhaps think, when Major Pollock says it is very easy to teach men scales and gradients, the difference between the magnetic and true North, and to set a sketch, and different things of that description, that he has gone a little too far, and that some of these matters are not so easily grasped by non-commissioned officers. His lecture, however, confirms me in the opinion I held, that all company conmanding officers are not alike, in fact that they are all not Major Pollocks; and that it is really almost impossible to hope that in a battalion you will get eight company commanders all sufficiently efficient to carry out the field training of their companies in the manner in which it should be done. I notice Nlajor Pollock speaks of captains commanding companies, but I would point out that under present rules in most battalions there are one or two companies which are usually conmanded by majors, and abroad I think nearly alway's three companies are commanded by field officers; and if I am not going off the line a little, and that in a discussion on the field training of companies, I may venture to touch on the organisation of our companies; this is the point that $I$ wish to lead up to, viz., that we should have our battalions organised into four double companies for tactical purposes. We must all recognise the importance of the command of a company, and it would be a great improvement $I$ think if for tactical purposes-I do not say for administrative purposes, such as pay, clothing, etc.-the battalion could be organised into four double companies under the four senior company commanders in the battalion. Major Pollock speaks in the lecture of the importance of preserving order as long as possible in the fight, 
disorder being inevitable, a mob, and different expressions of that kind. Now, if our battalions were organised in four double companies, we should, I think, put off disorder as long as possible. I do not know what reasons can be urged against this double company organisation, except perhaps the small detachments which sometimes have to be furnished in Ireland, or when some fifty or sixty men might be required suddenly to aid the civil power; it is then perbaps convenient to send one complete company as at present organised on such duties. There is possibly one other reason which might be advanced if double companies were adopted, that the civilian authorities following that silly system of comparing us with other countries might argue that we had too many officers for each double company, because, of course, then we should have a company commander who would be either a major or a senior captain, we should also have under him a captain and two or three subaltern officers, according as the battalion was on home or foreign service. The advantage of four double companies in each battalion would be, that they would be able to form their own firing line, supports, and reserve; and $I$ think with a strength of 200 men each double company would be sufficiently strong to carry it through most ordinary fights without getting into disorder or mixed with other companies. Reinforcing also would be much easier, and the mixture of units would be deferred as long as possible; and, lastly, we should have the best officer in command, that is, the four senior company commanders would be selected and be the most efficient officers of the battalion; in this way in peacetime, I venture to think, it could be relied on that the ficld training of companies would be carried out in the most thorough manner possible.

Colonel Lossdale A. Hale (late R.E.):--The lecturer has given some advice on the subject of the preparation of lectures, and I an afraid I do not agree with him at all in the advice he has given you. He says that tle lecture should be carefully prepared and written out before the training is commenced. He is against extemporary lectures. But do I understand him to say that he would have lectures to the men read, and not given extemporarily? I have had considerable experience in lecturing to stupid people, and even to Staff College students' classes in the hour after lunch, and 1 managed invariably to keep them awake, not from any eloquence on my part, but because my lecture was extemporary. The right way, to $\mathrm{my}$ mind, to deliver a lecture to anybody-a private soldier or anyone-is to write it out from beginning to end first of all, then reduce it to a series of long marginal notes, and then go over those marginal notes and see if they recall to you the paragraph to which they refer. Then reduce those marginal notes to a word, and continue until a word recalls five or ten minutes' speech. Then you can look at the soldiers all the time you are speaking to them, and you do not let them go to sleep. If you read, you cannot watch youraudience, and cannot see whether you are getting dull yourself - you cannot tell how they are taking it; but if you always have your eye upon your audience, if you find them inclined to be sleepy you, can try to rouse them up. Moreover, an audience does not like to go to sleep if you have your eye on them. I can assure you that the way to keep the attention of your audience is to get the lecture well up yourself, and then deliver it as if it were extemporary, and then you get the character of being a wonderful extemporary speaker besides. There is one point I should like the lecturer to tell us, viz., to what extent he intends in the company training to make the dressing of the extended line be preserved. He tells us that the dressing of the extended line is to be' carefully maintained, and he says the drill of the battalion is always carried on in the same way the extended line is to be dressed. Now, during the last few years at the manouvres I have generally been in the fighting line, and if there is a word that I absolutely loathe, and which I hear repeated over and over again, it is: "Men, keep your dressing." The whole of the extended line look to the flank, and never think of their section commanders at all; everybody tries to dress. Is not it right rather that the dressing of an extended line should not be what we call dressing; but when troops 
are extended, section leaders should see that the general front of the line is preserved, so that whether in open country or difficult country, the men should be listening to what the section leaders are saying, rather than keeping their eyes this way and that way, and not to the front?

Lieut.-General Lord Williay F. E. SEyol:R:-I have nothing to say, except to hope that every word that we have in this paper written by Major Pollock should be printed and sent to every commanding officer in the Army as a guide, instead of, or in addition to, the syllabus at present in use ; I feel quite sure that if that were done we should have the majority, inslead of the minority, of officers taking the same pains as Major Pollock seems to have done, and the same good results would be altained, according to the experience of Sir Richard Harrison.

Major Pollock, in reply, said :-I have never attempted debate before, and, therefore, if I am feeble in replying to what has been said, I hope that you will bear with me. I must begin, with reference to what General Gossett has said, by confessing honestly that I have not the remotest notion as to what is in Sec. 47 of the Drill Book.

General Gossetr :-It is with regard to training the recruit in the principles in which he should be drilled at recruits' drill, extended order, and so on.

Major Polzock :-Now I understand. Perhaps you will allow me to say what we do in this matter at the depôt of my own regiment where I am now stationed. 1 occasionally take the recruits out in the drill-field, but my general plan is this : About ten minutes before the end of the mid-day parade, I say to the instructor of the first squad, "March your squad on to the grass." (We happen to have some grass on the square.) They are formed in single rank. The remainder, down to the men in plain clothes who have joined that day, are put in the rear rank. Each first-squad man has thus to look after one of the younger hands, and put him right. Then I drill them in extended order by signal; I do not open my mouth. I do this three or four times a week, having men in the ranks, some with dummy rifles and some with nothing at all. I find that this plan works very well. It makes the men think. I taught one squad thoroughly; including casualties, last October twelve months. I have never taught anybody since. Now I never waste time in teaching anybody. I expect the old hands to teach the new ones, and they do so. General Gossett has an objection to the falling-out of casualties during drill manceuvres, on the ground that the men would skulk in actual battle. I think we may admit that men, who are going to skulk in battle, would skulk whether they had been taught to fall out as casualties or not. I cannot quite see General Gossett's objection. We can avoid casualties by reinforcing to the flanks, and so on, and widen the front as we go along, in the case of a small force; but when you have two or three brigades alongside one another I do not see how you can carry out the reinforcements without casualties.

General Gossert :-I wish to mention that last year, when in.command of a District in India, I refused to have any casualties at manceuvres. I wanted to see how it would work, and I attacked the position without reinforcenents. In certain places the men overlapped. But I did it for experiment, and nobody was killed; and I was very pleased.

Major Pollock:-But there was nobody shooting at you at the time. I think that simplifies a rather intricate arrangement. General Gossett says that in trying to get order out of disorder we go too far in creating it, and that that is a mistake. I do not think that the creation of disorder should be applied, intentionally, at manceurres. In company field training, where you are dealing with a company only, and the sections and sub-sections within that company, then is the time to teach how to get out of disorder. But when you come to the regular manceuvres of large bodies, I think you should aim at avoiding disorder, so far as is practicable. 
General Gossetr :-I think you misunderstood me; I was not speaking of training companies.

Major PoLlock:-We agree entirely there then. I think that in companytraining we should try to teach the men how to work in disorder and how to regain order; but in manceuvres we should try to go through the battle, and to preserve order if we can, with the idea that if we can preserve it in mancuvres we may have a chance of doing so, to a certain extent, in a real fight. General Gossett also drew attention to an obvious difficulty, which is, that we cannot have a perfectly-trained company, with every man fit to command a section, on account of the Reservemen. That is quite true; but the better-trained men we have got, the more easily they will carry those Reservemen along with them, just as I expect my first squad at the depôt to teach the yokel fresh from the plough. Sir William Cameron spoke of increasing the intelligence of recruits by constant catechising. I do not think we can do too much of that. In my own regiment men do plenty of it, and also in the depôt. In the battalion to which I belong, one of the arrangements is this : The colonel, we will say, is going round kits. The sergeant-major, or somebody else, goes on ahead, into a company barrack-room. To one man he says, "You are on sentry, No. 3 group, No. 4 pichet." To somebody else he says, "You are connecting file between No. 3 post and the picket." And to somebody else he says, "Yeu have just come to report to the commanding officer that you have seen the enemy at such and such a place." The colonel enters the room, and the sergeant-major says, "This is one of the men, sir." The colonel asks, "What are you?" He says, "I am Private Thomas Atkins, H Company, and Somersetshire Light Infantry, and I am on sentry-No. 3 group, No. 4 picket," or whatever it is. Another, on being addressed, answers, "I have been sent from No. 3 picket to report to the officer commanding that the enemy is coning on in such and such a place." We have that hind of thing going on constantly, and $I$ think that it promotes their intelligence, because they have to remember and they have to think. I agree most fully with what Sir William Cameron has said about its being absurd to waste too much time upon tent-pitching and other purely mechanical work. Such things are so easily learnt when they have to be done; but I think that a bit of bridging and lashing is very necessary.

Sir W'Illiay Camerox :-It should be done, but I say it is hardly necessary to do it in this very important company training. When you strike every man off duty once a year for a certain purpose, I say it is a pity to waste time then.

Major Pollock:-ls not it rather important to get one's own men together, and know what they are all good for?

Sir William Casieron:-You can have classes and do that throughout the year, without doing it at this special time.

Major Pollock :-Colonel Dooner speaks about scales, and so on. The following example will be an illustration of how I go to work in this and other things. I want to teach a man an idea of scales. I produce a photograph, and I say, "Now; look here; who is that?" "That is you,'sir." "Very well; how tall is that figure on that photograph?" He will say, perlaps, 5 inches. Then I say, "Just to oblige me, call it 6." "All right," he says, "we will make it 6." "Now, how high am I, do you think?" I suggest that I am 6 feet in my boots, then I say, "You see that photograph. There are 6 inches of picture representing a man 6 feet high. How much of the man would 1 inch of the photograph represent?" And from that we go on. And so in the same way about slopes. I take the ruler and the India rubber. I put the India rubber on the table and say, "You are to consider that 1 foot thick, and you are to consider that that ruler is $19 \cdot 1$ yards long." I explain that I do not understand why it is, but $I$ know it is a fact that if the slope of a hill is $1^{\circ}$ you have to walk up 19.1 yards before you rise a foot. Then I put a second piece of India rubber upon the first and say, "The rise is now 2 feet, 
with a slope $2^{2}$, and so on." It is unnecessary for me to say more, except that practical illustrations make instruction easy. Colonel Lonsdale Hale does not agree with lectures being read. Theoretically I entirely agree with him in that, but $I$ think in order to give a lecture extempore you must first get a man who can deliver it. I think that for ordinary people it is far better to read a lecture than to weary your audience by taking three or four times as long as is necessary to say what you have to say. I do not think your men will fall asleep if you pause and ask questions as you go along. I do not suggest that one should read the lectures right through, and then begin to catechise at the end; but a sentence may be read which introduces a point, and questions may be asked upon it. Then as to dressing the extended line, I do not mean that every individual man is to be correctly in line. In my paper I say, "Before undertaking to restore order, it is necessary to have so drilled the men that there shall be an 'order' to restore." This applies to the drill practised on the drill ground, but not to manœurres.

The Cirairmax (General Sir Richard Harrison):-Ladies and gentlemen, I am atware that in former years some regiments had something like the company training that we have now, but that was done chicfly by the energy of individual officers. It could not be done thoroughly, because under our Army system many men are taken away for garrison and regimental duties, and, consequently, companies could not be made up to their proper strength. I cannot help thinking that one of the best things that modern administration has done for our Army was the establishment, in, I think, the year 1883, of what is called "Company field training," which means that once a year every company in a battalion has to be made up to its full strength, with its non-commissioned officers and all possible men present, and put through a complete course of training for war under its own officers, the course to last about a month, or more if possible. Whether that instruction can be extended so that recruits, having been once passed by the adjutant, should be handed over to the captains or other officers of companies for complete training in all subjects is, perhaps, beyond the scope of our present discussion. Anyhow, Major Pollock has stuck to his text, and has confined himself to a description of the system he used for training his company. He has given us a very interesting illustration of how he worked, describing how he was able to produce order out of the inevitable disorder that must occur in the latter part of any hardly-contested fight. I do not think there is anything for me to notice in the discussion. We have had an extremely interesting one, and I am very glad we have had one. I am quite certain that this subject is one that interests a very large majority of officers in our Army, though, unfortunately, we have not been able to fill the room this afternoon as much as I should have liked. Speaking as a general officer who has lately commanded one of our districts in England, I must tell you that the difficulties that I encountered in carrying on this company training were not difficulties that occurred in the regiments thenselves. I had every possible assistance from them. The difficultics that I had to encounter were in obtaining suitable ground, in making a convenient annual time-table, and in providing the necessary stores. I am quite certain that if generals and staff officers and regimental officers work together, difficulties will vanish. I would like to give you a short illustration. IThen I went down to Devonport I discovered what Major pollock alluded to, that the companies were training simply on the brick-fields, which is a very hard place just outside the lines. I cast about to see whether I could find some ground that would suit the purpose better, and in riding about I found a bit of undulating ground, wooded here and there, between two of the outlying forts. I spoke to my staff officers and said, "Will this do?" "It will be too far off," I was told ; "the regiments will never get there." I said, "IVell, I think we will get over that difficulty; I am not sure that the march out and the march back won't be a good thing, and will be part of the training for the 
men." I then went to the commanding engineer and said, "I want that bit of ground." He said, "You cannot have it ; it is let." I said, "Let? It is Government ground; I suppose we can have it." He said, "I am afraid we can't. We shall have to write to the Secretary of State for War. I do not think there is a chance of your getting it." I said, "Will you let me see the lease?" He brought me the lease, and I took it home and read it. I found that this ground was let to Mr. Somebody-I forget his name-subject to usage by the troops at the station. Some previous. R.E. officer had made these good arrangements, but it had been gradually overlooked, and my friend the farmer had heen enjoying this land, which was exceedingly valuable, undisturbed, at a fraction of the rate at which land was let all round about. Needless to say, he did not have that enjoyment much Ionger, for I worried him pretty well. With reference to the distance of the ground from the barracks, I will just tell you a little anecdote. It happened that a foreign military attacht came down to stay with the Admiral at Devonport, and several officers were dining there one night, when the attache said, "You have no training to speak of in the English Army-nothing to what we have got. I should like to see any of your men run a couple of hundred yards." One of the officers said, "If you will come to our parade to-morrow morning, any company that you like to pick out shall run a mile." He said, "I do not believe that." However, he appeared at the parade on the following morning and chose a company. This company was in marching order, and fortunately it had just gone through its course of military training on the bit of ground that I have mentioned. The mile was measured, the company "doubled" the whole distance, and then charged across the squarc, cheering as they went. I never heard anything after that of the ground being too far from the barracks. It was evident that the march there and back and what they did there had thoroughy trained the men in wind, if in nothing else. The system of company training, as laid down in the Drill-Book, gives very great latitude to the regimental officers who have to carry it out; this is, no doubt, right in principle. But I cannot help saying this (which agrees to a certain extent with what General Gossett has said), that I think that for the company, at all events, some data should be given for formation for attack and defence, so that when two companies come together it will not be necessary to issue any special instructions to them. I believe it is quite practicable, and I cannot help thinking that it would be an exceedingly good thing. Some fifteen years ago $I$ had the honour of giving a lecture in the theatre of this Institutionthe old building-upon training for war, and I ventured to say that $I$ believed there was nomore honourable or interesting occupation in the whole world than that of training one's fellow men. I believe that this feeling is growing in our Army. Officers are now taking a great deal of trouble about this company training, and certainly the addition of company training to our regulations has not curtailed one jot the rush of young men to come into the service. I believe that company training will grow in favour the more it is thought about. Perhaps we may even see the day when it will be what Major Pollock has called "the backbone of infantry tactics." I feel sure that you will agree with me that Major Pollock has done a good thing in bringing the subject forward here in this Institution, and I call upon you to give him a hearty vote of thanks for having done so, 